Aleksandr V. Pigin

Petrozavodsk State University

Petrozavodsk

av-pigin@yandex.ru

\title{
A NEW BOOK ON OLD RUSSIAN DEMONOLOGY ${ }^{1}$
}

\begin{abstract}
Дмитрий И. АНтонов, Михаид Р. МАЙЗУ ҺЬС, Демоны и грешники в древнерусской иконографии: семиотика образа, Москва: Индрик, 2011, 384 с. с илд. ISBN 978-5-91674-149-0

[Dmitriy I. ANTONOV and Michael R. MAYZULS, Demons and Sinners in Old Russian Iconography: The Semiotics of the Image, Moscow: Indric, 2011, 384 p., with illustrations.]
\end{abstract}

In their book, historians Dmitriy Antonov and Michael Mayzuls deal with the iconography of 'The Enemy', addressing the way that demonic and infernal creatures are depicted in Old Russian icons and manuscript illuminations. Forays into this territory have been made as far back as in 1866, by Fedor Buslayev, ${ }^{2}$ but the topic has never before been covered comprehensively in a dedicated book. The volume under review is an attempt at an exhaustive analysis of the subject: it describes the system of traditional iconographic rules that prescribe a certain appearance to the devil, or the so-called visual 'grammar' of demonic imagery, while explaining the symbolic meaning of its elements (such as forelocks, beards, tongues, spots, horns etc); it touches upon the functioning of this imagery within society explaining, for instance, why the readers would sometimes erase the faces of demons and sinners in the manuscripts; it traces the evolution of visual demonology as a whole and of its particular elements; it defines the connection between the image and the literary text it illustrates or theological concept it is related to, as well as the interaction between the 'official' Orthodox Christian demonology and its ver-

(1) The present review was sponsored by the Petrozavodsk University Strategic Development Programme, 2012-2016.

(2) Ф. И. БуслАЕВ, “Бес”, in Мои досуги, т. 2, Москва, 1866, с. 1-23. 
nacular counterpart, and more. The research is based on several hundred manuscripts, mostly illuminated, found in Russian and European libraries and museum collections. Among those that feature most prominently are commemorative books with literary forewords, illuminated hand-written copies of the Life of St Basil the New, the Apocalypse, and 'Flower Gardens' (Tsvetniki) - illustrated anthologies made in Old Believer communities. Additionally, the authors refer to a large number of Russian icons depicting Judgement Day, Christ's Descent into Hell etc., while also analysing the Byzantine and Western European traditions in depicting the demonic. They demonstrate an extensive knowledge of the work undertaken in the field by European and American art historians and cultural historians, and this wider context allows them to both trace the origin of many elements of Old Russian visual demonology and to define the ways in which it is unique.

The book consists of four chapters: (1) The image of the Enemy in religious art; (2) Demons, sinners and monsters: the semiotics of the demonic; (3) The Danse Macabre of the late Middle Ages; (4) 'Pictures of hell': illustrated $17^{\text {th }}$ and $18^{\text {th }}$ century anthologies. A separate study describes the image of Death in Carpathian icons of Judgement Day. The structure of the book reflects the logic of the narrative: the authors proceed from global issues to specific ones, at the same time adhering to chronology. Even though the book touches upon a large number of aspects, the authors never lose sight of the key issues, concentrating on the crucial images of Old Russian demonology and eschatology (demons, the Devil, Antichrist, Death, Hell, Judas etc).

Of special interest are the authors' studies concerning the way that the text and the image interrelate. An icon or an illumination are never a simple picture to go with the text, they always have elements of text interpretation, which the book under review describes with copious examples. Sometimes the miniature includes information that is absent from the actual text; for instance, a $16^{\text {th }}$-century copy of the Lay of the Battle of Mamai has an illustration where an anthropomorphic bearded demon is portrayed, a demon prince, even though there is none in the text itself (p. 69). Another example is how Death is often presented as male in miniatures, even though the grammatical gender of the Russian word smert' is feminine, which is explained by the influence of the German pictorial tradition, the word Tod being grammatically masculine. There are also interesting examples of the way the pictures influence the text: for instance, one of the later cop- 
ies of the Life of St Basil the New adds a new detail to the description of death: it is "a mere skeleton of naked human bones," which can be traced back to Baroque iconography (p. 223). The description of demons in other Lives of saints sometimes mentions their 'pointed heads', which, again, is derived from the way they are depicted in icons and miniatures (p. 123). The abstract notions of old texts, such as Hell, Death etc, are given flesh in the pictures, made tangible and personal.

The $16^{\text {th }}$ and $17^{\text {th }}$ centuries, the authors note, see the emergence of a new and more complex iconography of the Enemy, and demonological plots become more numerous. This 'upsurge' of the demonic in the late Middle Ages, which has already been noted by other researchers, is partly explained by the influence of Western European culture, as well as by social disruption and the widespread apocalyptic sentiment of the period. The authors, however, do not consider the transformation of visual demonology to be a direct effect of these crises, proposing instead that imagery itself has a power to form and change public views and generate new political and theological ideas. It should also be noted that, according to Dmitry Likhachov, ${ }^{3}$ the $16^{\text {th }}$ century was also a time when the traditional system of literary images and devices began to disintegrate, leading to the emergence of completely new genres and styles a century later. The $17^{\text {th }}$ century gave us what Aleksey Remizov calls the two 'most demonic' tales the Tale of Solomonia the Possessed and the Tale of Savva Grudtsyn. The changes in literature and the pictorial system would often coincide, even though, as the authors point out, the demonology of the books was not as sophisticated and rich in detail as its visual counterpart.

Researching the so-called 'lesser eschatology', or the Christian teaching that concerns an individual death of a person, is also indispensable if a study of the world of demons and its visual representation aims to be complete - and the book under review delves into this subject as well. Demons are often depicted surrounding a person on their death-bed, tormenting sinners in Hell, meeting the soul in aerial toll-houses etc; these illustrations mostly come from various visionary texts, apocrypha, and texts from the Synaxarium and The Great Mirror included in illustrated $17^{\text {th }}$ and $18^{\text {th }}$ century anthologies. It is to this period that the majority of Russian illuminated manu-

(3) Д. С. ЛИХАчев, Поэтика древнерусской хитературы, Москва, 1979, c. 101. 
scripts used in the book belong (see list, pp. 335-339), although some were also made in the $19^{\text {th }}$ and even $20^{\text {th }}$ centuries; and it is this period, the transition from the Middle Ages to the Early Modern period, that gives a new boost to demonological iconography. Often, images in these books actually outweigh the text itself, the miniatures are frequently placed on foldout pages, there are more and more 'portraits' of various demonic personages, the torment of Hell is pictured in alarmingly naturalistic detail, and the demons are painted as huge. At the same time, as the authors point out, this obvious exaggeration and intimidation is also accompanied by an upsurge of the grotesque, which sometimes spills over into the comic (for instance, an $18^{\text {th }}$ century miniature is cited where demons are pictured stuck upside down into rounded hills). As the authors single out these two conflicting trends, they raise an interesting question of the balance between the fearsome and the funny in demonological imagery, and of its gradual secularisation, which takes the scholarly demonology of the $17^{\text {th }}$ and $18^{\text {th }}$ centuries closer to its folklore counterpart, where the image of the devil is ambivalent.

The observations the authors make are also very important for the study of later literature dealing with demonology and eschatology. Students of the $17^{\text {th }}, 18^{\text {th }}$ and $19^{\text {th }}$ century Russian 'instructive' tales will often find themselves wondering which principle is dominant in a given text, because it is not always easy to see whether this or that tale purports to teach doctrine, or be didactic, and thus to convince the reader of its authenticity, or be entertaining, and thus to hint at its being fictitious. ${ }^{4}$ Let me adduce two examples from my own research. Old Believer manuscripts often include a tale which claims to be taken from the book Starchestvo (The Book of Elders), structured as a dialogue between a Starets called Zacharias and his pupil called Euphymius, taking place "in a little monastery in the mountains, three miles from the town of Kartog, nigh Podolie, called Mekoezm" (found in such manuscripts as Kargopol State Museum of Fine Art, History and Architecture, KP-10238; Institute of Russian Literature (the Pushkin House), Russian Academy of Sciences, St Petersburg, Latgale collection No. 335; and others). They discourse "on Antichrist and his temptation, and on the signs of his hordes," and it would

(4) See some aspects of this problem in Е. К. РОМОДАНОВСКАЯ, Русская литература на пороге нового времени: Пути формирования русской беллетристики переходного периода, Новосибирск, 1994. 
seem that this topic would not allow any poetic licence in an Old Believer scribe. However, the names and the place are obviously fictional, even though the narrative follows the pattern of a paterikon; there are slightly frivolous details - for example, the temptations of Antichrist include "garters on the legs of females"; and the source cited does not exist - the copy of Starchestvo in question was allegedly printed in Krakow in 1027 (sic!); all of which suggests a strong presence of invention and the gradual emergence of fiction per se. A further example can be found in yet another manuscript, made in the late $18^{\text {th }}$ century; it is a tale falling into the "monk and devil" category, where a serious topic (the condemnation of tobacco smoking) and a somewhat comic image of the devil (who ends up deceived) are both present. It is made even more ironic by its verse form and a jocular claim that it is a translation "from the Armenian language." 5 The book under review also gives several examples of this demonological kind of belles lettres (p. 303).

Dmitriy Antonov and Michael Mayzuls also tackle the difficult subject of mysterious zoomorphic and anthropomorphic creatures, or ornamental beasts, found in Old Russian manuscripts and the decoration of Mediaeval churches of Vladimir and Suzdal. They note that the Russian animal style and the architectural bestiary as a whole do not correspond directly to canonical Christian demonology: only the small men in pointed hats found in these ornaments bear any similarity to elements of traditional demonological imagery (p. 281).

The book is amply illustrated, which allows the reader to trace the authors' way of interpretation of the images. The book reads very pleasantly, the extent of manuscript material used is formidable, and the ideas and interpretations proposed are original and new. Dmitriy Antonov and Michael Mayzuls have definitely made a considerable contribution to the study of Russian Mediaeval culture.

I would like to conclude by noting that, in 2014, Dmitriy Antonov and Michael Mayzuls published what can be regarded as a sequel to the book under review, an album entitled Анатомия ада: Путеводитель по древнерусской визуальной демонологии [The Anatomy of Hell: a Guide to Old Russian visual demonology] (Moscow: Forum; Neolit,

(5) А. В. Пигин, “К изучению демонологических сказаний о табаке: рукописная повесть конца XVIII - начала XIX века 'о мнихе и бесе'," in In Umbra. Демонология как семиотическая система, ред. Д. И. Антонов, О. Б. ХРИСтОфОРОвА, вып. 1, Москва, 2012, с. 331-344. 
2014). It contains 28 chapters of commentaries and approximately 300 miniatures, most of them previously unpublished. Besides, since 2012, Dmitriy Antonov has, together with social anthropologist Olga Khristoforova, been editing a yearly journal entitled In Umbra: Демонология как семиотическая система [Demonology as a semiotic system], which publishes articles not only on Christian demonology but also on various spirits and lesser demons found in other literary traditions, world art and folklore. 